http://dx.doi.org/10.4314/ajtcam.v10i4.22

\title{
CYTOTOXIC AND ANTIBACTERIIAL ACTIIVITY OF THE MIXTURE OF OLIVE OIL AND LIME CREAM IN VITRO CONDITIONS
}

\section{Zeynep Sumer, ${ }^{1}$ Gulay Yildirim, ${ }^{* 2}$ Haldun Sumer, ${ }^{3}$ Sahin Yildirim $^{4}$}

\author{
${ }^{1}$ Department of Microbiology, Faculty of Medicine, Cumhuriyet University, 58140-Sivas, Turkey. \\ ${ }^{* 2}$ Department of Medical Ethics and the History of Medicine, Cumhuriyet University, 58140-Sivas, \\ Turkey. \\ ${ }^{3}$ Department of Public Health, Faculty of Medicine, Cumhuriyet University 58140-Sivas, Turkey. \\ ${ }^{4}$ Department of Pharmacology, Faculty of Medicine, Cumhuriyet University, 58140-Sivas, Turkey. \\ *Email: gyildirimg@,gmail.com
}

\begin{abstract}
The mixture of olive oil and lime cream has been traditionally used to treat external burns in the region of Hatay/Antakya and middle Anatolia. Olive oil and lime cream have been employed by many physicians to treat many ailments in the past. A limited number of studies have shown the antibacterial effect of olive oil and that it does not have any toxic effect on the skin. But we did not find any reported studies on the mixture of olive oil and lime cream. The aim of this paper is to investigate the cytotoxic and antibacterial activity of olive oil and lime cream individually or/and in combination in vitro conditions, by using disk-diffusion method and in cell culture. The main purpose in using this mixture is usually to clear burns without a trace. Agar overlay, MTT (Cytotoxicity assay) and antibacterial susceptibility tests were used to investigate the cytotoxic and antibacterial activity of olive oil and lime cream. We found that lime cream has an antibacterial activity but also cytotoxic on the fibroblasts. On the other hand olive oil has limited or no antibacterial effect and it has little or no cytotoxic on the fibroblasts. When we combined lime cream and olive oil, olive oil reduced its cytotoxic impact. These results suggest that mixture of olive oil and lime cream is not cytotoxic and has antimicrobial activity.
\end{abstract}

Keywords: Olive oil, lime cream, burn, in vitro, cytotoxic activity, antibacterial activity

List of abbreviations: MTT $=$ Cytotoxicity assay; $\mathrm{OO}=$ Olive oil; $\mathrm{LC} / \mathrm{CC}=\mathrm{Lime}$ cream $/$ calcium chloride; $\mathrm{NIH}=\mathrm{National}$ Institute of Health; NCCAM= National Centre for Complementary and Alternative Medicine; CAM= Complementary and alternative medicine; DMEM=Dulbecco's modified eagle medium; IOS=International Organisation for Standardisation; FCS=Foetal calf serum; $\mathrm{DMSO}=$ Dimethylsulfoxide; $\mathrm{OD}=$ Optical density; Tukey HSD= Honestly significant difference

\section{Introduction}

Many researchers tried to achieve appropriate treatment methods to reduce the risk of wound infections and to shorten the period of treatment of patients with burn wounds. But one of the major problems in burns is mark left on the skin (Dai et al., 2010; Daryabeigi et al., 2010).

This is outside of the scientific quest; we came across traditional practices in the treatment of burns, especially plants oil and plants extract used in this treatment. Plants used in the treatment are older than the start. As in all countries of the world, important medicinal plants are being used among the people in Turkey for centuries (Kırbag, 2006).

Herbal medicine treatment methods are also being examined as alternative medicine to gain new drugs from the natural world. Due to their increasingly widespread applications around the world and the deficiencies in the literature, the National Institute of Health (NIH) of the National Centre for Complementary and Alternative Medicine (NCCAM) was established in the United States in 1999. The purpose of this Centre is to examine the safety and efficacy of applications, the effectiveness of treatments of complementary and alternative medicine (CAM) and practices to ensure the participation of scientifically proven efficacy of treatments (Bent and Ko, 2004).

Olive oil has been called liquid gold as it contains a high percentage single fatty acid. It is a good source of antioxidants with a high calorific value and a source of essential fatty acids and fat-soluble A, D, E, K vitamins tank. Olive oil is the unique vegetable oil which is produced naturally by physical methods obtained from olive fruit by pressing. Therefore, olive oil is capable of keeping natural features as vitamins, essential fatty acids and other nutritious ingredients (Unsal, 2000).

In the mythological stories of olive oil, olives were observed as the ointment that could treat the wounds of humanity (Unsal, 2000). Olive oil and lime cream have been employed by many physicians to treat many ailments in history (Nidai, 1567; Onler, 1990; Uzel, 1992; Kahya, 1995; Bayat, 2005; Canpolat, 2007; Pacacioglu and Yildirim, 2010).

Traditionally, Olive oil has been used for centuries in the treatment of hypertension, cholesterol, arteriosclerosis, gastric-intestinal ulcers, rheumatism, gall bladder, liver disorders, intestinal and skin diseases (Mana et al., 1997; Sugibayashi et al., 2002; Vissers et al., 2004; De la Torre Carbot et al., 2006; Medina et al., 2007; Verallo Rowell et al., 2008).

A lot of research works have been carried out on antioxidant, antibacterial, anti-inflammatory effects of Olive oil, 


\section{http://dx.doi.org/10.4314/ajtcam.v10i4.22}

but researches about cytotoxic effects are limited (Babich and Visioli, 2003).

Today, olive oil is still used in traditional applications, alone or with lime cream in different proportions (sense of proportion), especially in the region of Hatay in the treatment of burns. The mixture of olive oil and lime cream is used in the treatment of external burns. The main purpose in using this mixture is usually to clear burns without a trace.

The aim of this paper is to investigate the cytotoxic and antibacterial activity of olive oil and lime cream individually or/and in combination in vitro conditions, by using disk-diffusion method and in cell culture.

\section{Methodology}

The experiments were carried out at the Department of Microbiology, Cumhuriyet University School of Medicine and CÜTFAM (Cumhuriyet University Faculty of Medicine Research Center). Prior to the study, the approval of the ethics committee was obtained from Cumhuriyet University Faculty of Medicine Research Ethics Board.

\section{Preparation of examination materials Olive oil orjin}

Homemade olive oil and extra virgin olive oil produced in the region Ayvalik were used in our study.

\section{Preparation of lime cream}

In the study, limestone was used to obtain lime cream. Briefly, purchased commercial limestone was put in cold tap water and resettled. Then, we collected the superficial liquid and used it for the study.

\section{Microbial cultures and growth conditions}

A total of six microbial strains and two yeast strains were tested: Staphylococcus aureus (ATCC 29213), Staphylococcus aureus (ATCC 6538), Escherichia coli (ATCC 25922), Escherichia coli (ATCC 11230), Enterococcus faecalis (ATCC 15753), Candida albicans (ATCC 76615), Candida albicans (ATCC 10235) strains and Staphylococcus epidermydis isolated from patient samples. Cultures of yeast and bacterial strains were grown for 10 hours in brain heart broth (Difco) at $37 \pm 0.1^{\circ} \mathrm{C}$. At the end of incubation, under aseptic conditions, dilutions of each strain were prepared individually in $0.9 \%$ saline, equating to a $0.5 \mathrm{McFarland}$ Standard (approximately $10^{6}$ colony forming units (cfu) per ml) which was inoculated on to fresh Mueller-Hinton Agar (Oxoid CM0337) by means of a sterile cotton swab.

\section{Fibroblast Cell}

In this study, L929 cells (ATCC-NCTC CLONE 929) were used and the cells were obtained from Alum Institute Culture Collection, Ankara, Turkey. L929 cells were cultured in $100 \mathrm{ml}$ DMEM (Dulbecco's modified Eagle medium) (Sigma Aldrich Cheme, Germany) supplemented with $1 \mathrm{ml} \mathrm{L}$ - Glutamine (Biochrom KG, Berlin, Germany) $2.2 \mathrm{~g} / \mathrm{L}$ sodium bicarbonate (Sigma, MO) $0.1 \mathrm{mM}$ nonessential amino acids (Sigma, MO) $1 \mathrm{mM}$ sodium pyruvate (Sigma, MO) $4 \mathrm{ml}$ foetal calf serum Biochrom KG, Berlin, Germany) and $1 \mathrm{ml}$ penicilin/streptomycin (10 g/ml) (Biochrom KG, Berlin, Germany) L929 cells were then seeded on tissue culture dishes ( $15 \mathrm{~mm}$ deep and $35 \mathrm{~mm}$ in diameter) and 96 incubated in an incubator set $\left(37^{\circ} \mathrm{C}, 5 \% \mathrm{CO} 2\right)$. Fibroblasts, DMEM were incubated in the oven put into (Tuncel et al., 2006).

\section{Assay procedures \\ Antimicrobial activity assay}

The paper disc diffusion technique was used to test the olive oil with / without lime cream against bacteria and yeast. Sterile paper discs (Whatman no. 4 paper, $6 \mathrm{~mm}$ diameter) were loaded (absorbed) with $50 \mu 1$ calcium chloride/ lime cream (CC/LC) and olive oil (OO) at different intensities (\% $100 \mathrm{CC} / \mathrm{LC}, \% 50 \mathrm{CC} / \mathrm{LC}+\% 50 \mathrm{OO}, \% 40 \mathrm{CC} / \mathrm{LC}+\% 60 \mathrm{OO}$ ,\% $60 \mathrm{CC} / \mathrm{LC}+\% 40 \mathrm{OO}, \% 100 \mathrm{OO})$ and dried at $30^{\circ} \mathrm{C}$. Discs were applied to each Petri dish. Each plate included a negative control $\left(80 \%\right.$ ethanol) and a positive control $\left(0.9 \%\right.$ saline). The plates were incubated aerobically at $37^{\circ} \mathrm{C}$ for $24 \mathrm{~h}$. Experiments 3 times can be re-evaluated whether the results mean. Following this, plates were examined visually and any inhibition noted and its diameter measured $(\mathrm{mm})$ and recorded. As the diameter of disc was $6 \mathrm{~mm}$, inhibition zones less than $7 \mathrm{~mm}$ were not evaluated (Mahasneh and El-Oqlah, 1999; Sokmen et al., 2004). The inhibition diameter was an average of four measurements per disc, taken at four different directions $\left(0,45,90\right.$ and $\left.135^{\circ}\right)$ in order to avoid minimisation. As the diameter of disc was $6 \mathrm{~mm}$, inhibition zones less than $7 \mathrm{~mm}$ were not evaluated (Nieva Moreno et al.,, 1999).

\section{Cytotoxicity Test}

The cytotoxic effect of lime cream and olive oil was observed on L929 fibroblast cells. The cell viability test was taken as criterion.

\section{Agar overlay method}




\section{http://dx.doi.org/10.4314/ajtcam.v10i4.22}

neutral red was added to each tissue dish and incubated for 30 minutes. Excess dye was removed, and test specimens were placed on the agar surface so that the bottom surface of each specimen was in contact with agar. A phenol-impregnated blotting paper was used as positive control and a DMEM-impregnated blotting paper as negative control. The dishes were incubated for 24 hours. Thereafter, the cultures were examined under a microscope by one examiner experienced in the use of this evaluation technique. It should be noted that the identity of the specimens was not made known to the examiner.

Decolourised zones and cell lysis around and/or under the specimens were evaluated according to IOS 10993-13 (standard 14). Three specimens of each group were studied, and each test was repeated three times using the same test specimens. Cell lysis is defined as loss of cell membrane integrity, which is visible in light microscopy. In this study, cell lysis was scored as follows: $0=$ no cell lysis detectable; $1=$ less than $20 \%$ cell lysis; $2=20 \%$ to $40 \%$ cell 1 ysis; $3=>40 \%$ to $<60 \%$ cell lysis; $4=60 \%$ to $80 \%$ cell lysis; $5=$ more than $80 \%$ cell lysis. For each specimen, one score was given and the median score value for all parallels from each specimen was calculated for the lysis zone.

Cytotoxicity was then classified as follows: $0-0.5=$ non cytotoxic; $0.6-1.9=$ mildly cytotoxic; $2.0-3.9=$ moderately cytotoxic; $4.0-5.0=$ markedly cytotoxic. The median (instead of the mean) was calculated to describe the central tendency of the scores because the results were expressed as an index in a ranking scale (Tuncel et al., 2006).

\section{MTT Test}

Cell proliferation was tested using a 3-(4, 5-dimethylthiazol-2-yl)- 2, 5-diphenyl tetrazolium bromide (MTT) assay (MTT assay kit, Cayman, USA). For the assay, fibroblasts were grown at the tissue culture plate and harvested from a 25 $\mathrm{cm} 2$ flask and plated in 96-well flat bottom tissue culture plate at a concentration of $1 \times 10^{5}$ cells/well containing $100 \mu l$ of DMEM (supplemented with 10\% FCS). The cultures were examined by interference light microscopy to assess the status of the cells. Then, $100 \mu \mathrm{l}$ calcium chloride / lime cream (CC/LC) and olive oil (OO) at different intensities $(\% 100 \mathrm{CC} / \mathrm{LC}, \% 50$ $\mathrm{CC} / \mathrm{LC}+\% 50 \mathrm{OO}, \% 40 \mathrm{CC} / \mathrm{LC}+\% 60 \mathrm{OO}, \% 60 \mathrm{CC} / \mathrm{LC}+\% 40 \mathrm{OO}, \% 100 \mathrm{OO}$ ) were added to the plate-wells. Experiments were repeated 11 times for each concentration. Control wells were prepared by harvesting fibroblasts from a fresh culture flask and plating cells at a concentration of $1 \times 10^{5}$ cells $/ \mathrm{ml}(100 \mu 1$ per well), and alcohol was used for negative control and DMEM was used for positive control in quadruplicate wells. The culture plate was incubated at $37^{\circ} \mathrm{C}$ in a $\mathrm{CO} 2$ incubator for $24 \mathrm{~h}$. The medium was removed from all the wells and $100 \mu \mathrm{l}$ fresh DMEM was added to each well. Then, about $20 \mu \mathrm{l}$ of MTT dye $(5 \mathrm{mg} / \mathrm{ml}$ of phosphate buffered saline (pH 7.2) stock, Sigma) was added to all the wells and the plate was incubated at $37^{\circ} \mathrm{C}$ in a $\mathrm{CO} 2$ incubator. After $4 \mathrm{~h}, 150 \mu 1$ of dimethylsulfoxide (DMSO, Sigma) was added to all the wells to dissolve the formazan crystals and the optical density (OD) was measured at a test wave length of $490 \mathrm{~nm}$ on microplate reader (Ozdemir et al., 2009).

\section{Statistical analysis}

Data were analysed statistically using Kruskal-Wallis one-way analysis of variance and Mann-Whitney U-test. Level of significance was set at $p=0.05$. (ANOVA) and Tukey HSD (honestly significant difference) tests were statistically compared with the evaluation.

\section{Results}

Compared to the mean, optical densities of the test are determined by ELISA reader (-) control with lime cream (LC) / calcium chloride (CC) between the control + olive oil (OO) and OO (60\%) + CC/LC (40\%). Significant differences were observed between the olive oil (OO) and $\mathrm{OO}(60 \%)+\mathrm{CC} / \mathrm{LC}(40 \%)$ and lime cream, and $(+)$ the difference between the control was statistically significant (Table 1).

Table 1: MTT test optical density averages

\begin{tabular}{lll}
\hline$\underline{\text { Groups }}$ & $\underline{\text { Ort. } \pm \text { SD }}$ & $\underline{\text { Test }}$ \\
\hline$(-)$ Control & $0.264 \pm 0.054$ & \\
Olive oil (OO) & $\begin{array}{l}\mathrm{F}=21.034 \\
\mathrm{P}=0.000\end{array}$ \\
$\begin{array}{l}\text { Lime Cream/Calcium Chloride } \\
(\mathrm{LC} / \mathrm{CC})\end{array}$ & $0.149 \pm 0.017$ & \\
$\begin{array}{l}\text { OO }+ \text { LC/CC } \\
\text { (+) Control }\end{array}$ & $0.310 \pm 0.103$ & \\
\end{tabular}




\section{http://dx.doi.org/10.4314/ajtcam.v10i4.22}

The vitality of cells was evaluated with microscope using neutral red in the agar overlay test. When the calcium chloride / lime cream (CC/LC) was cytotoxic on cells, Olive Oil (OO) had no cytotoxic effects. We observed limited cytotoxicity in the mix of $(\mathrm{OO})(60 \%)+(\mathrm{CC} / \mathrm{LC})(40 \%)$ (Table 2$)$.

Table 2: Agar overlay test viability assessment results

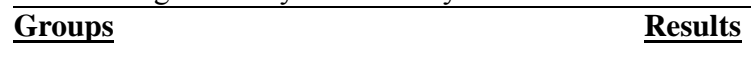

(-) Control ++++

Olive oil (OO)

Lime Cream/Calcium Chloride

$(\mathrm{LC} / \mathrm{CC})$

$\mathrm{OO}+\mathrm{LC} / \mathrm{CC}$

$++$

$(+)$ Control

(-) cytotoxic
$(+)$ noncytotoxic

According to the results of our disk diffusion test, all tested strains of bacteria and yeast were susceptible to calcium chloride. The lowest zone diameters 9mm of Staphylococcus aureus (ATCC 29213) and the upper one 25mm of Staphylococcus epidermidis were observed. When olive oil was used alone, it was the most effective on Enterococcus faecalis (ATCC 15753) (10mm), and also it was effective on two bacteria (Escherichia coli (ATCC 11230 and Staphylococcus epidermidis), and did not affect two Candida strains. CC/LC + OO (\% $40+\% 60)$ mix did not decrease antibacterial activity. The results are given in Table 3.

Table 3: Test results of antibiotic screening

\begin{tabular}{|c|c|c|c|c|c|c|c|}
\hline \multirow[t]{3}{*}{$\underline{\text { Microorganisms }}$} & \multirow{3}{*}{$\begin{array}{l}\text { Negative } \\
\text { control } \\
\text { (\%9 NaCL) }\end{array}$} & \multicolumn{5}{|c|}{ Effective Diameter (mm) } & \multirow[t]{3}{*}{ positive control } \\
\hline & & \multirow[t]{2}{*}{$\mathbf{L C}^{*}$} & \multirow[t]{2}{*}{$\mathbf{O O}$} & $\mathrm{LC}+\mathrm{OO}$ & $\mathrm{LC}+\mathrm{OO}$ & $\mathrm{LC}+\mathrm{OO}$ & \\
\hline & & & & 4060 & 5050 & $60 \quad 40$ & \\
\hline $\begin{array}{l}\text { Staphylococcus aureus } \\
\text { 29213) }\end{array}$ & & 9 & 8 & 9 & 9 & 9 & 14 \\
\hline Staphylococcus aureus (ATCC 6538) & - & 14 & 8 & 10 & 12 & 12 & 19 \\
\hline Escherichia coli (ATCC 25922) & - & 14 & 9 & 10 & 11 & 12 & 14 \\
\hline Escherichia coli (ATCC 11230) & - & 13 & - & 9 & 11 & 12 & 19 \\
\hline Enterococcus faecalis (ATCC 15753) & - & 19 & 10 & 14 & 17 & 19 & 17 \\
\hline Candida albicans (ATCC 76615) & - & 20 & - & 13 & 14 & 16 & 25 \\
\hline Candida albicans (ATCC 10235) & - & 18 & - & 15 & 16 & 18 & 20 \\
\hline Staphylococcus epidermidis & - & 25 & - & 20 & 20 & 20 & 25 \\
\hline
\end{tabular}


http://dx.doi.org/10.4314/ajtcam.v10i4.22

L929
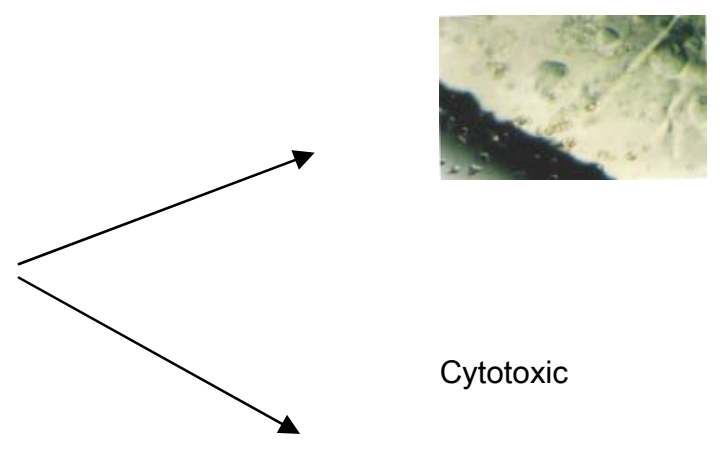

Cytotoxic
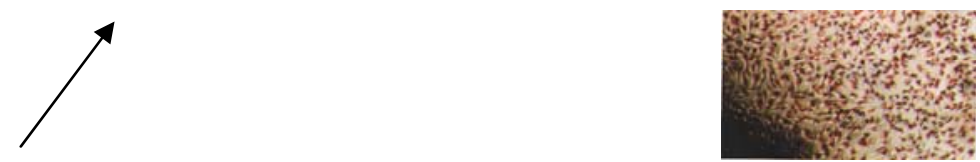

Noncitotoxic

Olive oil
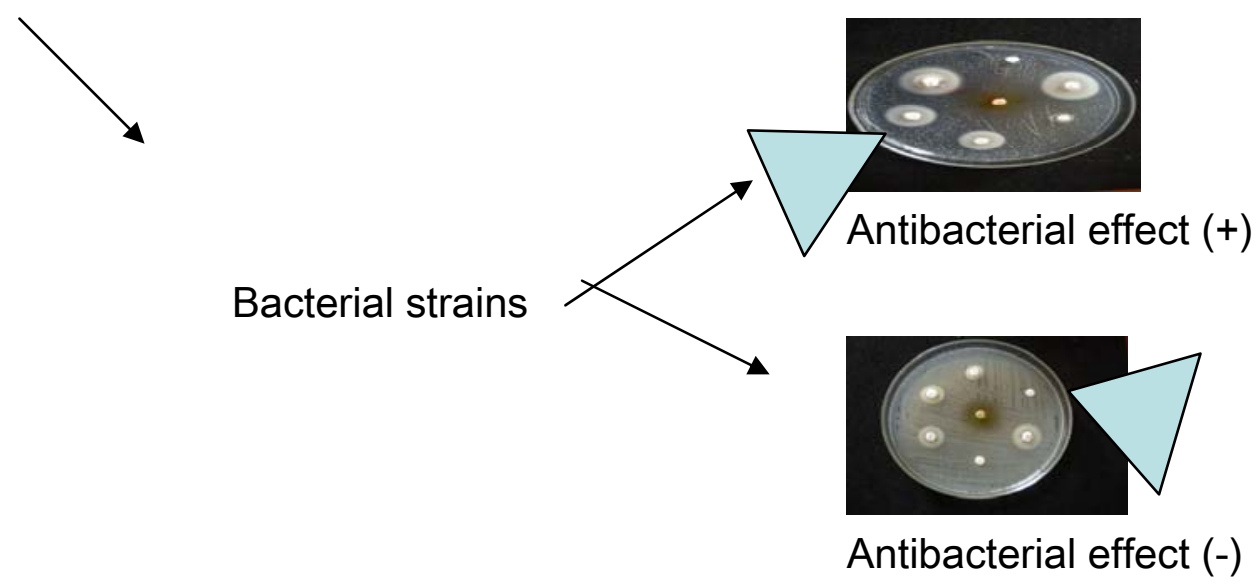

Figure 1: Mixture of olive oil and lime cream cytotoxic and antimicrobial activity

\section{Discussion and Conclusion}

Especially, the second degree burns were very painful injuries that require emergency response. People use various traditional applications to reduce the pain. The mixture of olive oil and lime cream is one of the traditional applications used in the region of Hatay in Anatolia. Among the people of Hatay was the belief that this mixture reduced both the pain and treated the remaining burn. We investigated the cytotoxic and antibacterial activity of olive oil and lime cream individually 


\section{http://dx.doi.org/10.4314/ajtcam.v10i4.22}

or/and in combination in vitro conditions, by using disk-diffusion method and cell culture in this paper. We used different proportions of these two substances. We found that lime cream has an antibacterial activity but also cytotoxic on the fibroblasts. On the other hand, olive oil has limited or no antibacterial effect and it has little or no cytotoxic on the fibroblasts. When we combined lime cream and olive oil, olive oil reduced its cytotoxic impact.

Babich et al. (2003) showed that olive oil has no cytotoxic effects on human gingival cells by using neutral red viability test. Sugibayashi and his friends (2002) researched the effects of olive oil on the live skin cells of dermal irritants in their studies. They demonstrated that olive oil did not have any cytotoxic effects on the skin. This study supports the results of these other studies and the data seem to support the plan forward for our work. Said and colleagues (2007) used olive oil as a control in their study about the effects of vegetable oils. The lack of cytotoxic effects was observed in these oils: Aleurites, camelina, maize, and olive. None of the oils showed any in vivo ocular irritation.

Shikov et al. (2008) reported that some oil extracts, like Chamomilla recutita oil extract, have antibacterial activity. In their study, Romero et al., (2007) investigated the antibacterial effect of olive oil on 3 different types of H. pylori strains and showed that olive oil extracts, rich in phenolic compounds, had antibacterial effects on H.pylori. Kubo and his colleagues (1995) observed antimicrobial activity of olive oil flavour compounds. Bisignano and his colleagues (1999) also observed different rates of resistance and sensitivity of oleuropein and hydroxytyrosol on the 5 standard and 44 strains isolated from patients in their study. Oleuropein is a product of olive.

The study of antibacterial effects of olive oil in other studies showed different sensitivities. This explains and confirms the low sensitivity in our results.

We could not find any study about lime cream. We have discovered antibacterial effect of lime cream on 6 bacteria and 2 yeast strains, although it was cytotoxic on fibroblasts. Cytotoxic effect of lime cream was decreased when combined with olive oil. Also, this decrease explains why the toxic effects of lime cream were not observed among the people in the past in their use of the lime cream and olive oil mixture.

In conclusion, the experiment shows tested actions: one is the effect of lime cream as an antibacterial factor and whether olive oil inhibits this (beneficial) effect; the other is the cytotoxicity of the lime cream against cells in the wound (non-beneficial effect) and whether these cells may be protected by the presence of olive oil. We have shown that mixture of olive oil and lime cream is not cytotoxic and has antimicrobial activity (Figure1). The test appears to decrease the quantity of lime cream used when the mix is made up on the paper so that any effect could possibly be due simply to a decreased amount of lime cream used. This is the first such report to show the in vitro effects of a traditional application. As a result of data from this study, in vivo experiments should be done in future.

\section{References}

1 Babich H, Visioli F (2003). In vitro cytotoxicity to human cells in culture of some phenolics from olive oil. Farmaco. 58(5): 403-7.

2. Bayat AH. Abdülvehhab bin Yusuf ibn-i Ahmed el- Mardani, Kitabu'l-Müntehab fi't-T1b,1420 (2005). (1420, old manuscripts of works). Published by Merkezefendi Geleneksel Tip Dernegi, Istanbul. (In Turkish)

3. Bent S, Ko R (2004). Commonly used herbal medicines in the United States: a review. The Journal of Medicine. 116: 478485 .

4. Bisignano G, Tomaino A, Lo Cascio R, Crisafi G, Uccella N, Saija A (1999). On the in-vitro antimicrobial activity of oleuropein and hydroxytyrosol. J Pharm Pharmacol. 1(8): 971-4.

5. Canpolat M, Onler Z (2007). İshak bin Murad, Edviye-i Müfrede. (XIV. Century, old manuscripts of works). Published by Türk Dil Kurumu Yayınları, Ankara. (In Turkish)

6. Dai T, Huang YY, Sharma SK, Hashmi JT, Kurup DB, Hamblin MR (2010). Topical Antimicrobials for Burn Wound Infections. Recent Pat Antiinfect Drug Discov. 1;5(2): 124-51.

7. Daryabeigi R, Heidari M, Hosseini SA, Omranifar M (2010). Comparison of healing time of the $2^{\text {nd }}$ degree burn wounds with two dressing methods of fundermol herbal ointment and $1 \%$ silver sulfadiazine cream. Iran J Nurs Midwifery Res. 15(3): 97-101.

8. De la Torre Carbot K, Jauregui, O, Castellote AL, Lamuela-Raventos RM, Covas MI, Casals I, Lopez-Sabater MC (2006). Rapid HPLC-ESI-MS/MS method for qualitative and quantitative analysis of virgin olive oil phenolic metabolites in human lowdensity lipoproteins. J Chromatography A. 1116: 69-75.

9. Kahya E. İbn-i Sina El Kanun fit' Tibb (1995). (11.Century, old manuscripts of works). Published by Atatürk Kültür Merkezi, Ankara. (In Turkish)

10. Kırbag S (2006). Elazıg yöresindeki bazı tıbbi bitkilerin antimikrobiyal aktivitesi (Antimicrobial activity of some medicinal plants in Elazig region). Journal of Agricultural Sciences. 16(2): 77-80. (In Turkish)

11. Kubo A, Lunde CS, Kubo I (1995). Antimicrobial activity of the olive oil flavor compounds. J Agric. Food Chem. 43: 162933.

12. Mahasneh AM, El-Oqlah AA (1999). Antimicrobial activity of extracts of herbal plants used in the traditional medicine of Jordan. Journal of Ethnopharmacology. 64: 271-76.

13. Mana C, Galletti P, Cucciolla V, Moltedo O, Leone A, Zappia V(1997). The protective effect of the olive oil polyphenol (3,4dihydroxyphenyl)-ethanol counteracts reactive oxygen metabolite-induced cytotoxicity in Caco-2 cells. J Nutr. 127: $286-92$.

14. Medina E, Romero C, Brenes M, De Castro A (2007). Antimicrobial activity of olive oil, vinegar, and various beverages 


\section{http://dx.doi.org/10.4314/ajtcam.v10i4.22}

against foodborne pathogens. J Food Prot. 70(5): 1194-9.

15. Nidai. Manzume-i Tibb. (1567). (old manuscripts of works). Pacacioglu's special library.

16. Nieva Moreno MI, Isla MI, Cudmani NG, Vattuone MA, Sampietro AR (1999). Screening of antibacterial activity of Amaicha del Valle (Tucuman, Argentina) propolis. Journal of Ethnopharmacology. 68: 97-102.

17. Onler Z. Celâlüddin Hızır (Hacı Paşa) Müntahab-1 Şifâ (1990). (1381, old manuscripts of works). Published by Türk Dil Kurumu, Ankara, 559 pp. (In Turkish)

18. Ozdemir KG, Yilmaz H, Yilmaz S (2009). In vitro evaluation of cytotoxicity of soft lining materials on L929 cells by MTT assay. J Biomed Mater Res B Appl Biomater. 90(1): 82-6.

19. Pacacioglu B, Yildirim G. Nidai’nin Kitabı: Manzume-i Tıbb (Nidai’s Book: Manzûme-i T1bb) (2010). J Med Ethics. 18(2): 71-9. (In Turkish)

20. Romero C, Medına E, Vargas J, Brenes M, De Castro A (2007). In vitro activity of olive oil polyphenols against helicobacter pylori. J. Agric. Food Chem. 55: 680-6.

21. Said T, Dutot M, Christon R, Beaudeux JL, Martin C, Warnet JM, Rat P (2007). Benefits and side effects of different vegetable oil vectors on apoptosis, oxidative stress, and P2X7 cell death receptor activation. Investigative Ophthalmology \& Visual Science. 48(11): 500-6.

22. Shikov AN, Pozharitskaya ON, Makarov VG, Kvetnaya AS (2008). Antibacterial activity of chamomilla recutita oil extract against helicobacter pylori. Phytother. Res. 22: 252-3.

23. Sokmen A, Gulluce M, Akpulat H. Daferera D, Tepe B, Polissiou M, Sokmen M, Sahin F (2004). The in vitro antimicrobial and antioxidant activities of the essential oils and methanol extracts of endemic thymus spathulifolius. Food Control. 15: 62734.

24. Sugibayashi K, Watanabe T, Hasegawa T, Takahashi H, Ishibashi T (2002). Kinetic analysis on the in vitro cytotoxicity using living skin equivalent for ranking the toxic potential of dermal irritants. Toxicol In Vitro. 16(6): 759-63.

25. Tuncel A, Ozdemir AK, Sumer Z, Hurmuzlu F, Polat Z (2006). Cytotoxicity evaluation of two different composites with/without fibers and one nanohybrid composite. Dent Mater J. 25(2): 267-71.

26. Unsal A (2000). Ölmez ağacın peşinde/ Türkiye'de zeytin ve zeytinyağı (Die in pursuit of the tree / olive and olive oil in Turkey). Published by Yapı Kredi, İstanbul. (In Turkish)

27. Uzel I. Şerafeddin Sabuncuoğlu Cerrahiyyetü'l-Haniyye (1992). Vol.1. (1465, old manuscripts of works). Published by Atatürk Kültür, Dil Tarih Yüksek Kurumu, Ankara, 416 pp. (In Turkish)

28. Verallo Rowell, VM, Dillague KM, Syah-Tjundawan BS (2008). Novel antibacterial and emollient effects of coconut and virgin olive oils in adult atopic dermatitis. Dermatitis. 19(6): 308-15.

29. Vissers, MN, Zock PL, Katan MB (2004). Bioavailability and antioxidant effects of olive oil phenols in humans: a review. European Journal of Clinical Nutrition. 58: 955-65. 